\title{
METHODICAL ASPECTS OF DETERMINATION OF PARAMETERS WHICH CHARACTERIZE THERMAL BALANCE OF A PLASTIC TUNNEL ${ }^{1}$
}

\author{
Sławomir Kurpaska*, Wojciech Lis, Jan Vogelgesang \\ Institute of Agricultural Engineering and Informatics, University of Agriculture in Krakow \\ *Corresponding author: e-mail: rtkurpas@cyf-kr.edu.pl
}

\begin{tabular}{|c|c|}
\hline ARTICLE INFO & ABSTRACT \\
\hline $\begin{array}{l}\text { Article history: } \\
\text { Received: March } 2016 \\
\text { Received in the revised form: } \\
\text { June } 2016 \\
\text { Accepted: August } 2016\end{array}$ & $\begin{array}{l}\text { The paper presents methodology of measuring the values which } \\
\text { characterize the thermal balance in a horticultural facility. Thermal } \\
\text { transmittance through a plastic tunnel cover and the ratio of solar } \\
\text { radiation energy conversion into heat were analysed in detail. The } \\
\text { research was carried out in real time with closed ventilators, where no }\end{array}$ \\
\hline $\begin{array}{l}\text { Key words: } \\
\text { plastic tunnel, } \\
\text { ratio of thermal transmittance, } \\
\text { coefficient of solar radiation, } \\
\text { conversion into heat }\end{array}$ & $\begin{array}{l}\text { plants were cultivated during the tests. The utility surface area was } \\
144 \mathrm{~m}^{2} \text {, the cover was } 289 \mathrm{~m}^{2} \text { and its volume was } 508 \mathrm{~m}^{3} \text {. Basing on } \\
\text { the standard relations, first of all, thermal transmittance through } \\
\text { a cover was measured. The ratio was measured with the use of stand- } \\
\text { ard criteria equations. Then, a correlation equation, which makes its } \\
\text { course dependent on the climate parameters (the wind speed and } \\
\text { temperature difference between the interior of the facility and its } \\
\text { surroundings), was found. Knowing the course of the ratio in the } \\
\text { function of the climate parameters, the value of the ratio of solar } \\
\text { radiation conversion into heat stored in the facility was measured. } \\
\text { Both parameters (thermal transmittance and solar radiation conversion } \\
\text { ratios) were calculated from the thermal balance equation where the } \\
\text { change of the energy stored inside the facility was compared to the } \\
\text { heat losses through a cover (for thermal transmittance) and the profit } \\
\text { (in case of solar radiation conversion). For the obtained values, using } \\
\text { the non-linear estimation procedure (with quasi-Newton method with } \\
\text { maintenance of the correlation coefficient of } 0.001 \text { ) the change of both } \\
\text { ratios in the function of easily measured parameters of climate inside } \\
\text { and outside the facility was found out. In the investigated conditions, } \\
\text { the average value of thermal transmittance through a cover was } 5.32 \\
\text { W· } \mathrm{m}^{-2} \cdot \mathrm{K}^{-1} \text {, and the solar radiation conversion into heat was } 0.36 \text {. The } \\
\text { values and their course from the climate parameters inside and outside } \\
\text { the facility may be used for controlling the amount of supplied heat } \\
\text { and location of ventilators. }\end{array}$ \\
\hline
\end{tabular}

1 This Research was financed by the Ministry of Science and Higher Education of the Republic of Poland 


\section{The list of symbols:}

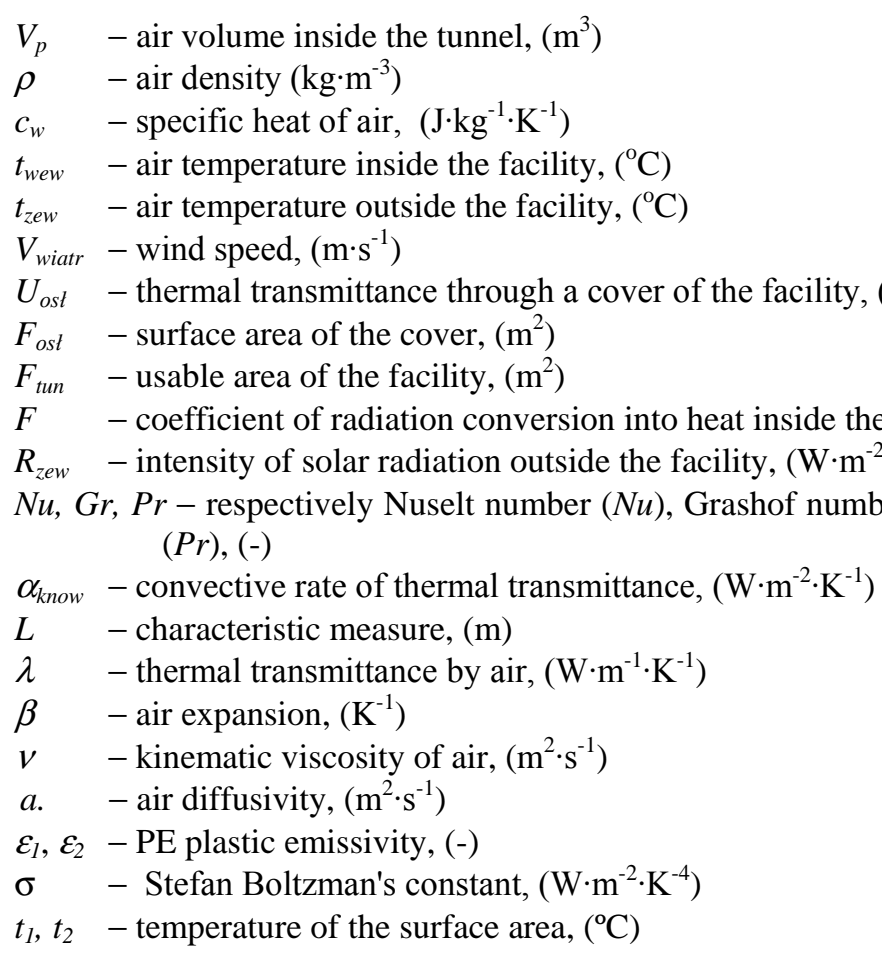

\section{Introduction}

In the production carried out in controlled conditions there is a need to use natural resources of the surrounding climate in the maximum scope. Connecting the solar radiation conversion into heat with the amount of the supplied heat is an example of such challenge in the horticultural facility. A transparent cover of the facility causes that the solar radiation which gets inside is converted into heat increasing the internal temperature. In case of intensive solar radiation this process implies the need to decrease the heat amount supplied by the heating system. The problem of intensity of fresh air supply in the ventilation process of the facility is integrally related with this issue. Thus, selection of regulation settings of the heating system, degree of opening ventilations without taking into consideration the amount of heat supplied through solar radiation conversion increases the heat consumption. The issue of thermal management in the facility including the solar radiation conversion was the area of research carried out in various scientific centres. Al-Helal and Abdel-Ghany (2011) determined a quantity impact of heat from conversion on the temperature increase inside the laboratory greenhouse and heat consumed for the phase transmission of the cultivated plants. The analysis includes a temporary variability of their value and the quantity participation of radiation on the temperature raise of the analysed components of the system. Hassanien et al. (2016) made a synthetic review (along with the economic analysis) of the 
Methodical aspects of determination...

introduced technical solutions which use solar radiation energy for ensuring the required environmental conditions in a greenhouse. Abdel-Ghany (2011) analysed the quantity solar radiation conversion into heat which causes the increase of temperature inside the greenhouse and the heat utilised for phase transmission. He determined temporary variability of heat streams which get inside a greenhouse exchanged with the surroundings and accumulated in soil. He also analysed the change of the radiation conversion into heat of phase transition and heat which causes the temperature change inside the facility. Lamnatou and Chemisana (2013) in their review paper analysed the impact of the applied structure of the cover in a greenhouse on the conditions of solar radiation conversion which gets to plants. The authors recommended some of those covers for solar conditions. They stated that miniaturized Fresnel lens integrated with glass may be applied to cover the south part of the greenhouse roof. El-Maghlany et al. (2015) based on theoretical discussion stated the impact of parameters of the roof ellipse and orientation towards the geographic axis of the plastic tunnel on the amount of heat which gets to its interior from solar radiation. The authors for the investigated region provided optimal values of the roof ellipse and determined savings in heat consumption by the considered facility. Singh et al. (2015) analysed availability of light for the greenhouse located in various regions of the globe and recommended that among the available sources, lighting with LED lamps brings the best financial effects in case of plant production. They found out that only a precise selection of wave lengths adjusted to the cultivated plants will give a positive effect. Martinovic and Simon (2014) developed assumptions of the system in which controlling basic parameters of the microclimate inside a greenhouse is made with the use of a mobile meteorological station. The authors concluded that the equipment of the system which enables measurement of external and internal conditions inside a greenhouse is an indispensable element and control of executive elements should be based on the fussy sets theory. Ntinas et al. (2014) provided structural details of the heat storage system inside a greenhouse in the water batteries located under cultivation drainpipes. The authors developed a mathematical model of the considered system in which they included balance equations which cover the increase of the energy stored in batteries in the period of intensive radiation and heat transfer to the inside of the facility in the period when heat was in demand. Vadiee and Martin (2014) analysed the impact of technical solutions on the strategy of managing the supplied heat for heating a greenhouse taking into account minimization of costs. Among the analysed solutions (heat screens, cover with greater insulation, heat screens and the system which minimizes ventilation of the facility) the use of solutions which limit ventilation brings the best financial effects. Canakci et al., (2013) analysed the costs of heating the greenhouses located in the region of the Mediterranean emphasising the necessity of optimal control of microclimate parameters. Cabrera et al. (2009) presented results of research on the percentage share of diffusive solar radiation which gets to the cover of a greenhouse with a dispersion into: the absorbed energy stream, reflected from the surface of the cover and the one which gets inside the facility. The conclusion states, inter alia, that diffusive radiation inside the facility may be estimated based on the knowledge of its value outside. Raczek and Wachowicz (2014) developed a mathematical model of heat and mass exchange inside a greenhouse and its solutions and simulations were carried out based on MATLAB program. It was found out that in order to use this model for the purpose of controlling microclimate parameters its detailed calibration to the real facility is indispensable. Kurpaska (2014) presented methodology of estimation of energy profits with the use of glass with varied emissivity as 
a cover. The achieved effects (including the average annual conditions of the surroundings) were calculated into fuel consumption and environmental effects.

The quoted literature proves that the issue of optimal use of available solar radiation is a present research problem. Conversion of this radiation is varied and depends on the conditions of the surrounding climate. Therefore, the main objective of the paper is to analyse the parameters which determine the thermal balance of the facility including heat transmission through the cover and intensity of solar radiation conversion into heat.

\section{Material and method}

The investigations were carried out in a plastic tunnel located in the facilities of the University of Agriculture in Krakow. The tunnel is covered with double plastic and there is white plastic on the floor. The following were measured-temperature - with Pt-1000 measuring instruments, relative moisture of air - with HD 4917 measures, wind speed - a cap anemometer, solar radiation intensity with LP PYRA 02AV pyranometer. Schematic representation of the test stand was presented in figure 1.

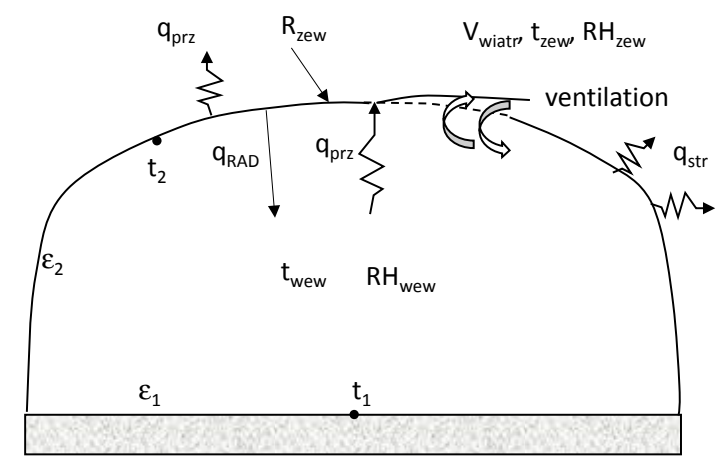

Figure 1. Schematic representation of the test stand

The tests were carried out in two stages, namely with and without radiation weather. Temporary variability of the temperature inside facilities was measured.

The process of heat exchange between the tunnel and surroundings may be described (for determined conditions) as a balance of its particular elements, namely:

- in case of solar radiation fading: change of the energy stored inside the tunnel is equal to the heat transmitted by radiation and convection from the external layer of the ground and is equal to the heat transmitted to the surroundings. The rate of heat transmission through a cover measured in those conditions (depending on the parameters of an experiment) constituted basis for calculations used in the conditions of radiation weather,

- in the conditions of radiation weather, the growth of energy inside the facility results from solar radiation conversion decreased by the heat losses to the surroundings.

Thus, in the time interval accepted for analysis $(d \tau)$ the energy balance of the analysed volume of the tunnel within the period of solar radiation fading may be written down as: 
Methodical aspects of determination...

$$
V_{p} \cdot \rho \cdot c_{w} \frac{d t_{\text {wew }}}{d \tau}=q_{\text {konw }}+q_{R A D}=U_{\text {ost }} \cdot F_{\text {ost }} \cdot\left(t_{\text {wew }}-t_{\text {zew }}\right)
$$

On the other hand, in the conditions of radiation weather, the balance may be written as follows:

$$
V_{p} \cdot \rho \cdot c_{w} \frac{d t_{\text {wew }}}{d \tau}=f \cdot F_{\text {tun }} \cdot R_{\text {zew }}-U_{\text {ost }} \cdot F_{\text {ost }} \cdot\left(t_{\text {wew }}-t_{\text {zew }}\right)
$$

The ratio of convective and radiation heat exchange between the external layer of the ground and the inside of the tunnel was described with the standard relations in the form of:

$$
N u=0,135 \cdot(G r \cdot \operatorname{Pr})^{0,33}
$$

Particular similarity numbers (Nusselt's, Grashof's and Prandtl's number) are provided with the following formulas:

$$
N u=\frac{\alpha_{k o n w} \cdot l}{\lambda} ; \quad G r=\frac{\beta \cdot g \cdot l^{3} \cdot \Delta T}{v^{2}} ; \quad \operatorname{Pr}=\frac{v}{a}
$$

As a characteristic dimension $(l)$ a relation of a fourfold surface area of a tunnel to its circumference was accepted and $\Delta T$ is a difference of temperature between the area of the ground and the inside of the facility.

On the other hand, replacing emissivity $\left(\varepsilon_{e f}\right)$ of the external layer of ground was calculated from the relation:

$$
\varepsilon_{\text {ef }}=\frac{1}{\frac{1}{\varepsilon_{1}}+\frac{F_{\text {tun }}}{F_{\text {ost }}}\left(\frac{1}{\varepsilon_{2}}-1\right)}
$$

Therefore, particular heat streams (convection: qkonw) and radiation (qRAD) may be described as follows:

$$
q_{\text {konw }}=\alpha_{\text {konw }} \cdot F_{\text {tun }} \cdot\left(t_{1}-t_{\text {wew }}\right) \quad \text { oraz } \quad q_{R A D}=\sigma \cdot \varepsilon_{\text {ef }} \cdot F_{\text {tun }} \cdot\left(\left(t_{1}+273\right)^{4}-\left(t_{2}+273\right)^{4}\right)
$$

The presented methodology proves that firstly for the solar radiation a convective ratio of heat transmission $\left(\alpha_{\text {konw }}\right)$ was measured with the use of criteria equations and then convection and radiation streams were determined. Next, heat transmission $\left(U_{o s t}\right)$ was measured and correlation equation was found out. This equation makes its course dependent on the climate parameters (wind speed and difference in temperature between the inside of the facility and its surroundings). Knowing the course of the ratio as a function of the climate parameters, the value of the ratio of solar radiation conversion into heat stored in the facility was measured. Both parameters (thermal transmittance and solar radiation conversion ratios) were calculated from the thermal balance equation where the change of the energy stored inside the facility was compared to the heat losses through a cover (for thermal transmittance) and the profit (in case of solar radiation conversion).

Any and all parameters indispensable for determination of these dependencies which describe the climate and microclimate in the facility were controlled and archived by the computer measuring system. The analysis assumed that the cover temperature $\left(\mathrm{t}_{2}\right)$ is equal $t_{2}=0,4 \cdot t_{\text {zew }}+0,6 \cdot t_{\text {wew }}$ (Kurpaska, 2007). Air density, its relative heat was calculated 
with the use of standard psychometric relations. Quantity measures of approximation (compliance) of the parameter calculated from the measures to the values approximated by the model were determined from the square mean error, known from error account $(\sigma)$.

\section{Results and discussion}

The analysis assumed PE plastic emission ratio $\left(\varepsilon_{1}, \varepsilon_{2}\right)$ at the level of 0.15 ; the surface area of the tunnel is $144 \mathrm{~m}^{2}$, the surface area of the cover is $290 \mathrm{~m}^{2}$, and inside the tunnel there is $508 \mathrm{~m}^{3}$ of air. During research, relative moisture of air inside the facility was within 13 to $90 \%$. Calculations were carried out for the time interval of $300 \mathrm{~s}$. The tests were carried out within the following variables of parameters:

$$
\begin{gathered}
-2,9 \leq t_{\text {wew }} \leq 42,9{ }^{\circ} \mathrm{C} ;<V_{\text {wiatr }}<2,2 \mathrm{~m} \cdot \mathrm{s}^{-1} ;-3,0 \leq t_{\text {zew }} \leq 41,5^{\circ} \mathrm{C} ; \\
6 \leq R_{\text {zew }} \leq 556 \mathrm{~W} \cdot \mathrm{m}^{-2}
\end{gathered}
$$

When taking all measurements, ventilations in the tunnel were closed and no plants were cultivated in the facility.

Figure 2 presents average values of heat amount (with division into heat exchanged by convection and radiation) as a function of average temperature difference (calculated between the inside and the surroundings of the facility).

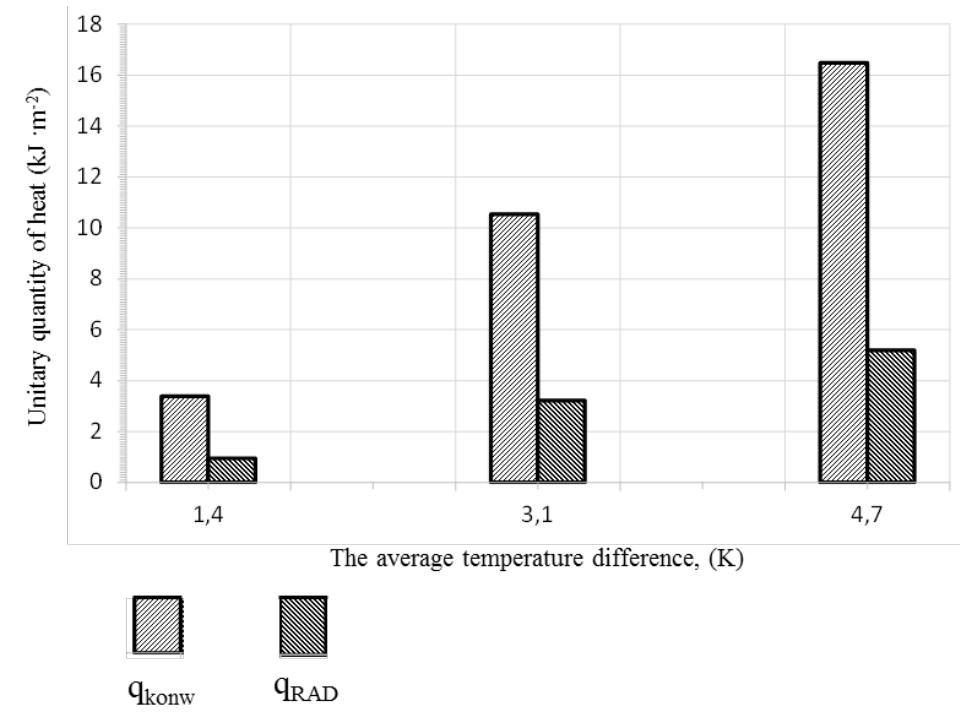

Figure 2. Amount of heat exchanged inside the facility as a function of temperature difference

As you may see, along with the increase of the temperature difference between the inside and the surroundings the amount of heat transmitted between the heated surface and the surface of the facility floor increases. It may be justified with two mechanisms, namely 
Methodical aspects of determination...

with the change in the intensity of heat exchange and the increasing heat losses by the cover of the facility.

Figure 3 presents the change of the value of the ratio of heat transmission through the facility cover. It may be noticed that along with the increase of temperature, the value of the ratio increases. In the investigated scope of difference between the temperature inside the tunnel and the temperature of the surrounding air $(\Delta t)$ and the wind speed during experiments, the scope of changes of the value of the heat transmission ratio is within 3.5 to 7.8 and its average value is $5.32 \mathrm{~W} \cdot \mathrm{m}^{-2} \cdot \mathrm{K}^{-1}$.

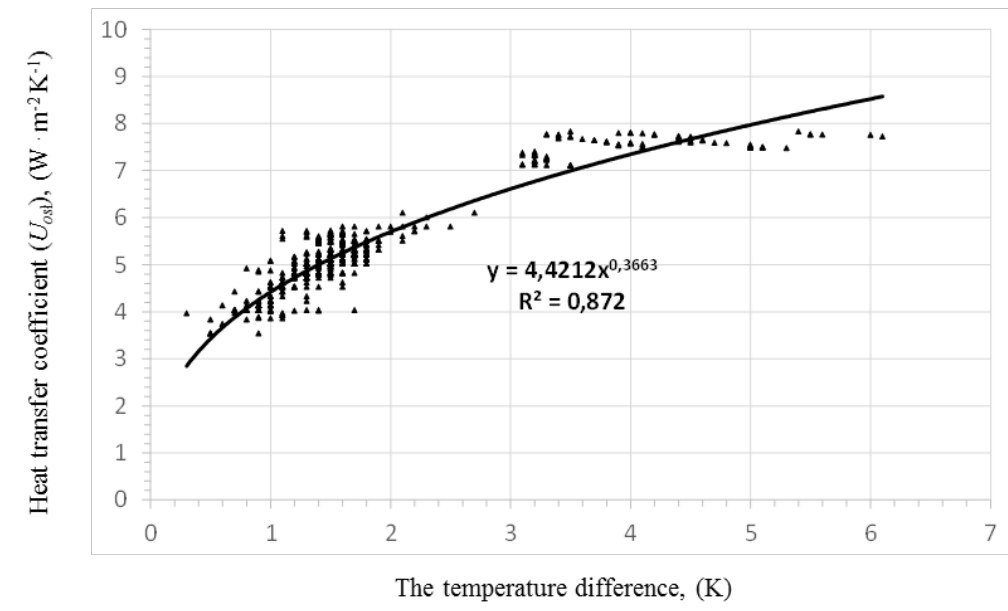

Figure 3. Course of changes in the value of heat transmission ratio through cover of the facility as a function of temperature difference

For the calculated ratio $U_{\text {ost }}$, equation which was found out and which includes the relation between this variable and independent variables: the wind speed and temperature difference between the inside of the tunnel and the surroundings (the form of a power model was selected based on the highest value of determination coefficient; this relation was determined with a non-linear estimation with quasi-Newton method at the retained coefficient of convergence of 0.001) takes the following form:

$$
U_{\text {ost }}=0,44 \cdot V_{\text {wiatr }}+4,37 \cdot \Delta t^{0,398} \quad R^{2}=0,89
$$

Within the scope of use: $0 \leq V_{\text {wiatr }} \leq 1,8 \mathrm{~m} \cdot \mathrm{s}^{-1} ; 0,3 \leq \Delta t \leq 6,1 \mathrm{~K}$

Figure 4 presents a comparison between the values of the coefficient calculated directly from the measurements and the values approximated by the found relations.

As you may see, the average square error which was formed from the used formula is $0.34 \mathrm{~W} \cdot \mathrm{m}^{-2} \cdot \mathrm{K}^{-1}$ which proves high adjustment of the obtained results with the found out approximated function.

Figure 5 presents a calculated ratio of solar radiation conversion into heat as a function of solar radiation intensity within the experimental parameters. 


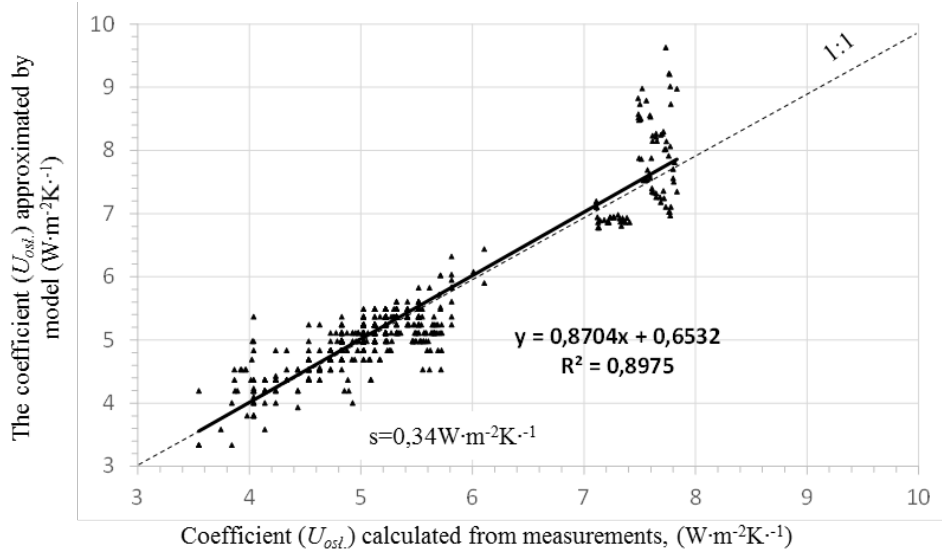

Figure 4. Comparison between calculated and approximated value of the ratio of heat transmission through cover of the tunnel

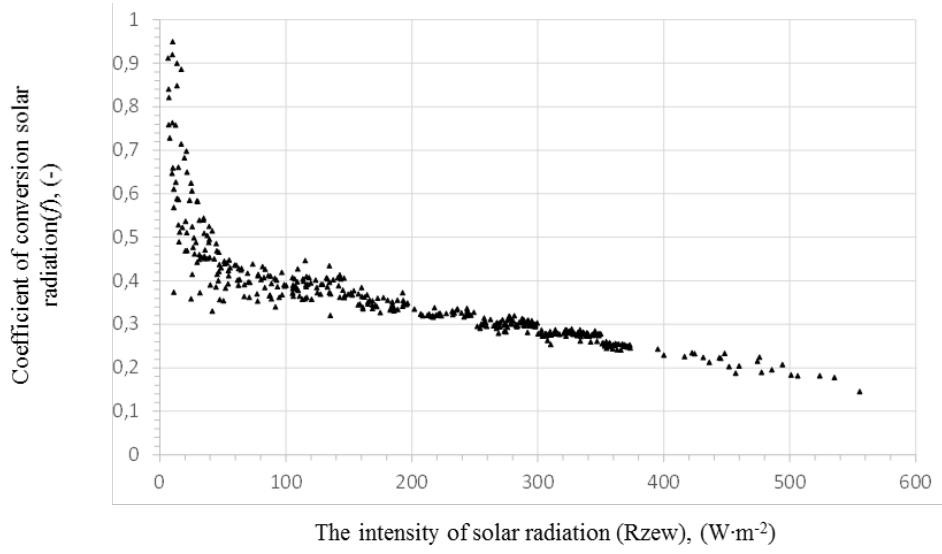

Figure 5. Ratio of solar radiation conversion into heat as a function of radiation intensity

One may notice that the analysed ratio achieves the highest value at the minimal value of irradiation. It results from the low value of air temperature inside the facility which causes that a considerable part of solar radiation is changed into the increase of the stored energy. Along with the increase of radiation intensity the temperature grows inside the facility which leads to the increase of the heat losses. The average value of conversion ratio in the investigated conditions is 0.36 and the scope of changes (depends on the solar radiation intensity) is within 0.15 to 0.95 . When comparing the obtained value of the ratio $(f)$ with the values obtained for facilities with plants, a lower value of this coefficient may be determined. It results from the plants transpiration process during which solar radiation energy used for the process of phase transmission of water evacuated by their stomas. 
Methodical aspects of determination...

Similarly, in case of heat transmission ratio and using an identical procedure, the power model which allows approximation of the value of the radiation conversion ratio $(f)$ takes the following form:

$$
f=-0,00075 \cdot t_{\text {zew }}+0,021 \cdot V_{\text {wiatr }}+1,23 \cdot R_{\text {zew }}{ }^{-0,24}
$$

Within the scope of use: $-3,0 \leq t_{o t} \leq 41,5^{\circ} \mathrm{C} ; 0<V_{\text {wiatr }}<2,2 \mathrm{~m} \cdot \mathrm{s}^{-1} ; 6 \leq$ $R_{\text {zew }} \leq 556 \mathrm{~W} \cdot \mathrm{m}^{-2}$

As one may see, this ratio is a rising function of wind speed; in case of the remaining variables, their increase caused decrease of the analysed ratio.

Figure 6 presents a comparison of the values calculated from the recommended model and the measured values. It is noticeable that the comparison is characterized with high compliance; average square error $(\sigma)$ is 0.069 .

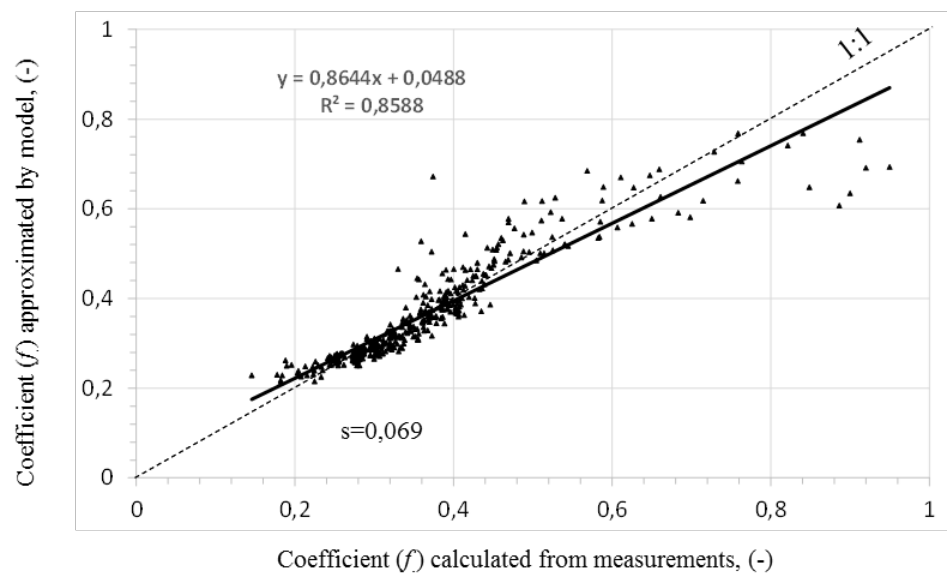

Figure 6. Comparison between values calculated and determined by measurements and value of the solar radiation conversion ratio.

When analysing the values obtained from the comparison of the approximated values from the recommended models with the values calculated from measurements (figure 4 and 6) one may notice that the slope of regression equations in both cases are lower than the unity at a small positive absolute term, which proves that the values calculated from models decrease the analysed sizes.

\section{Conclusion}

1. The scope of changes of the value of the ratio of heat transmission through the cover of the facility is within 3.5 to 7.8 and its average value is $5.32 \mathrm{~W} \cdot \mathrm{m}^{-2} \cdot \mathrm{K}^{-1}$.

2. The equation which approximates the value of the ratio of heat transmission through the facility cover takes the following form:

3. $U_{\text {ost }}=0,44 \cdot V_{\text {wiatr }}+4,37 \cdot \Delta t^{0,398} R^{2}=0,88$ 
4. Within the use: $0 \leq V_{\text {wiatr }} \leq 1,8 \mathrm{~m} \cdot \mathrm{s}^{-1} ; 0,3 \leq \Delta t \leq 6,1 \mathrm{~K}$.

5. The average value of conversion ratio in the investigated conditions is 0.36 and the scope of changes (depends on the solar radiation intensity) is within 0.15 to 0.95 .

6. The relation which allows calculation of the value of the ratio of solar radiation conversion into heat may be written down as:

$$
f=-0,00075 \cdot t_{\text {ot }}+0,021 \cdot V_{\text {wiatr }}+1,23 \cdot R_{\text {zew }}{ }^{-0,24}
$$

Within the scope of use:

$$
-3,0 \leq t_{\text {ot }} \leq 41,5^{\circ} \mathrm{C} ; 0<V_{\text {wiatr }}<2,2 \mathrm{~m} \cdot \mathrm{s}^{-1} ; 6 \leq R_{\text {zew }} \leq 556 \mathrm{~W} \cdot \mathrm{m}^{-2}
$$

\section{References}

Abdel-Ghany, A.M. (2011). Solar energy conversions in the greenhouses. Sustainable Cities and Society, Vol. 1, 219-226.

Al-Helal, I.M., Abdel-Ghany, A.M. (2011). Energy partition and conversion of solar and thermal radiation into sensible and latent heat in a greenhouse under arid conditions. Energy and Buildings, Vol. 43, 1740-1747.

Cabrera, F.J., Baille, A., Lopez, J.C., Gonzalez-Real, M.M., Perez-Parra, J. (2009). Effects of cover diffusive properties on the components of greenhouse solar radiation. Biosystems Engineering, Vol. 103, 344- 356.

Canakci, M., Emekli, N.Y., Bilgin, S., Caglayan, N. (2013). Heating requirement and its costs in greenhouse structures: A case study for Mediterranean region of Turkey. Renewable and Sustainable Energy Reviews, Vol. 24, 483-490.

El-Maghlany, W.M., Teamah, M.A., Tanaka, H., (2015). Optimum design and orientation of the greenhouses for maximum capture of solar energy in North Tropical Region. Energy Conversion and Management, Vol. 105, 1096-1104.

Hassanien, R., H. E., Li, M., Lin, W.D. (2016). Advanced applications of solar energy in agricultural greenhouses. Renewable and Sustainable Energy Reviews, Vol. 54, 989-1001.

Kurpaska, S. (2014). Energy effects during using the glass with different properties in a heated greenhouse. Technical Sciences, Vol. 17(4), 351-360.

Kurpaska, S. (2007). Szklarnie i tunele foliowe. Inżynieria i procesy. PWRiL, Poznań. ISBN 978-8309-01024-1.

Lamnatou, Chr., Chemisana, D., (2013). Solar radiation manipulations and their role in greenhouse claddings: Fresnel lenses, NIR- and UV-blocking materials. Renewable and Sustainable Energy Reviews, Vol. 18, 271-287.

Martinovic, G., Simon, J., (2014). Greenhouse microclimatic environment controlled by a mobile measuring station. NJAS - Wageningen. Journal of Life Sciences, Vol. 70-71, 61-71

Ntinas, G.K., Fragos, V.P., Nikita-Martzopoulou, Ch. (2014). Thermal analysis of a hybrid solar energy saving system inside a greenhouse. Energy Conversion and Management, Vol. 81 428439.

Raczek, A., Wachowicz, E. (2014). Heat and mass exchange model in the air inside a greenhouse. Agricultural Engineering. Vol. 149, 185-195.

Singh, D., Basu, Ch., Meinhardt-Wollweber, M., Roth, B. (2015). LEDs for Energy Efficient Greenhouse Lighting. Renewable and Sustainable Energy Reviews, Vol. 49, 139-147.

Vadiee, A., Martin, V. (2014). Energy management strategies for commercial greenhouses. Applied Energy, Vol. 114, 880-888. 
Methodical aspects of determination...

\section{METODYCZNE ASPEKTY WYZNACZANIA PARAMETRÓW CHARAKTERYZUJĄCYCH BILANS CIEPLNY TUNELU FOLIOWEGO}

Streszczenie. W pracy przedstawiono metodyke do wyznaczania wielkości charakteryzujące bilans cieplny w obiekcie ogrodniczym. Szczegółowej analizie poddano współczynnik przenikania ciepła przez transparentną osłonę tunelu foliowego oraz współczynnik konwersji energii promieniowania słonecznego w ciepło. Badania przeprowadzono w rzeczywistym obiekcie przy zamkniętych wietrznikach, w którym podczas badań nie uprawiano roślin. Powierzchnia użytkowa tunelu wynosiła 144 $\mathrm{m}^{2}$, osłony $289 \mathrm{~m}^{2}$, zaś jego pojemność była równa $508 \mathrm{~m}^{3}$. Bazując na standardowych zależnościach w pierwszej kolejności wyznaczono współczynnik przenikania ciepła przez osłonę. Współczynnik wyznaczono korzystając ze standardowych równań kryterialnych. W następnej kolejności znaleziono równanie korelacyjne uzależniające jego przebieg od parametrów klimatu (prędkość wiatru oraz różnica temperatury między wnętrzem obiektu a jego otoczeniem). Dysponując przebiegiem współczynnika w funkcji parametrów klimatu, w następnym etapie wyznaczono wartość współczynnika konwersji promieniowania słonecznego $\mathrm{w}$ ciepło zmagazynowane w obiekcie. Obydwa parametry (współczynnik przenikania ciepła oraz konwersji promieniowania słonecznego) wyliczono z równania bilansu ciepła, w którym porównano zmianę energii zmagazynowanej wewnątrz obiektu ze stratami ciepła przez osłonę (dla przenikania ciepła) oraz zyskiem (w przypadku konwersji promieniowania słonecznego). Dla uzyskanych wartości, korzystając z procedury estymacji nieliniowej (metodą quasi-Newtona przy zachowanym współczynniku zbieżności 0,001 ) znaleziono zmienność obydwu współczynników w funkcji łatwo mierzalnych parametrów klimatu wewnątrz i na zewnątrz obiektu. W badanych warunkach, średnia wartość współczynnika przenikania ciepła przez osłonę była równa $5,32 \mathrm{~W} \cdot \mathrm{m}^{-2} \cdot \mathrm{K}^{-1}$, zaś współczynnika konwersji promieniowania słonecznego $\mathrm{w}$ ciepło wyniosła 0,36 . Znalezione wartości i ich przebieg od parametrów klimatu wewnątrz i na zewnątrz obiektu można wykorzystać do sterowania ilością dostarczanego ciepła oraz położeniem wietrzników.

Słowa kluczowe: tunel foliowy, współczynnik przenikania ciepła przez osłonę, współczynnik konwersji promieniowania słonecznego w ciepło 